
Not for reproduction, distribution or commercial use.

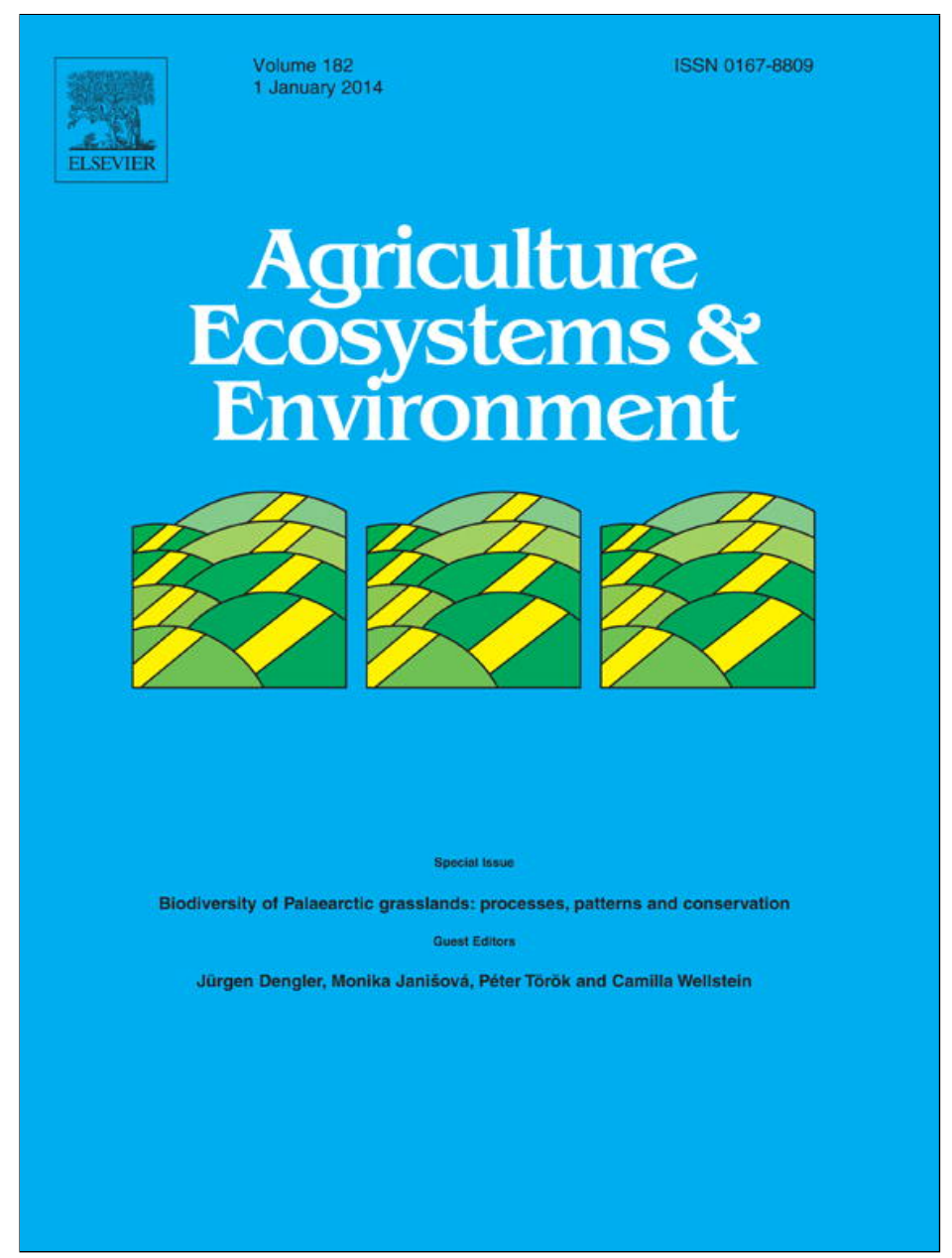

This article appeared in a journal published by Elsevier. The attached copy is furnished to the author for internal non-commercial research and education use, including for instruction at the authors institution and sharing with colleagues.

Other uses, including reproduction and distribution, or selling or licensing copies, or posting to personal, institutional or third party websites are prohibited.

In most cases authors are permitted to post their version of the article (e.g. in Word or Tex form) to their personal website or institutional repository. Authors requiring further information regarding Elsevier's archiving and manuscript policies are encouraged to visit:

http://www.elsevier.com/authorsrights 


\title{
Landscape effects on diversity of semi-natural grasslands
}

\author{
${\text { Monika Janišováa, }{ }^{a}, \text { Dana Michalcová }}^{b}$, Giovanni Bacaro $^{c}$, Anne Ghisla $^{\mathrm{d}}$ \\ a Institute of Botany, Slovak Academy of Sciences, Ďumbierska 1, 97411 Banská Bystrica, Slovakia \\ ${ }^{\mathrm{b}}$ Department of Botany and Zoology, Faculty of Science, Masaryk University, Kotlářská 2, 61137 Brno, Czech Republic \\ ' Bioconnet, Biodiversity and Conservation Network, Department of Environmental Science 'G. Sarfatti', University of Siena, 53100 Siena, Italy \\ ${ }^{\mathrm{d}}$ GIS and Remote Sensing platform, Biodiversity and Molecular Ecology Department, Research and Innovation Centre - Fondazione Edmund Mach, Via E. \\ Mach 1, 38010 S. Michele all'Adige, Italy
}

\section{A R T I C L E I N F O}

\section{Article history:}

Received 6 August 2012

Received in revised form 23 May 2013

Accepted 30 May 2013

Available online 2 July 2013

\section{Keywords:}

Alpha diversity

Gamma diversity

Habitat diversity

Mass effect

Multiplicative beta diversity

Natural habitat

Non-natural habitat

Spatially constrained rarefaction

Species pool

Vascular plants

Vegetation-plot database

\begin{abstract}
A B S T R A C T
We studied how the landscape structure (percentage cover and diversity of surrounding habitats) affects different components of species diversity (alpha, beta and gamma) of vascular plants in semi-natural grasslands in the Slovak Republic. We analyzed all grasslands combined as well as four main types delimited according to their position along a moisture gradient (xerophilous, sub-xerophilous, mesophilous and wet grasslands). We used grassland records stored in the Slovak Vegetation Database. The geographically stratified dataset included 3795 plots with 1221 species of vascular plants. Along with the total number of species in the vegetation plots, we considered the numbers of target grassland species, forest species, archaeophytes, neophytes and species with high fidelity to non-natural habitats. The landscape parameters based on CORINE land cover maps and the National Grassland Inventory, were calculated for plot neighbourhoods of $4 \mathrm{~km}^{2}$. Spatially constrained rarefaction curves were constructed to examine how different diversity components behave with changing structure of the surrounding landscape. Our study revealed that alpha diversity was affected by both percentage cover and diversity of different habitats in the plot neighbourhood. It increased with increasing proportion or diversity of different natural and semi-natural habitats and decreased with increasing proportion or diversity of non-natural habitats in the surrounding landscape. Beta and gamma diversities showed opposite pattern to that of alpha diversity for most analyzed factors. Alpha diversity in sub-xerophilous and mesophilous grasslands was more susceptible to changes in landscape structure than alpha diversity in xerophilous or wet grasslands. Regression trees and linear or quadratic regression models revealed that in xerophilous or wet grasslands, high alpha diversity was best predicted by a high proportion of ecologically valuable grasslands in the surroundings. In sub-xerophilous and mesophilous grasslands, the best predictor was proportion of natural and semi-natural habitats followed by the proportion of non-natural habitats. The detected pattern regarding alpha, beta and gamma diversity calculated for grassland target species did not differ from the pattern for the whole species assemblage. However, the surrounding landscape affected the number, proportion and cover of species typical of forest or non-natural habitats (including alien species) in the plots. We explain the results by the interplay of two main mechanisms: species pool and spatial mass effects. In our study, the effect of species pool on alpha diversity was stronger than the spatial mass effect. Based on differences indicated in the responses of various grassland types to the surrounding landscape structure, we suggest adoption of community type specific conservation measures
\end{abstract}

(c) 2013 Elsevier B.V. All rights reserved.

\section{Introduction}

Semi-natural grasslands represent, regardless of their relatively small extent, a notable part of the Central European landscape. Their importance lies, among other things, in their extraordinarily high species richness, which is partly due to the combined influence of natural and human activities (Ellenberg, 1996). A comparative

\footnotetext{
* Corresponding author. Tel.: +421 908553509.

E-mail address: monika.janisova@savba.sk (M. Janišová).
}

study conducted by Wilson et al. (2012), considers certain types of these grasslands, especially those with a long management history (Hájková et al., 2011), as the most species-rich vegetation in the world at small grain sizes.

The permanent loss of grassland diversity since the midtwentieth century, caused mainly by changes in landscape management (e.g. Chytrý, 2012; Eriksson et al., 2002), has motivated intensive research on mechanisms that influence grassland plant diversity. Plant diversity patterns have been predominantly explained by local determinants, such as soil properties, management and land use history, disturbance or biotic interactions 
(e.g. Bruun et al., 2001; Grime, 2001; Michalcová et al., 2011; Reitalu et al., 2012). Less frequently, it has also been explained by regional processes, such as climate, size and habitat age (e.g. Bruun, 2000; Cousins and Eriksson, 2002; Öster et al., 2007). However, it has been recognized that plant community structure and diversity may also be affected by neighbouring habitats via effects on the regional species pool and dispersal limitations (Akatov et al., 2005; Pärtel et al., 1996; Söderström et al., 2001; Zobel, 1997). It is supposed that the habitats surrounding certain plant communities represent sources of species which are not regular components of the given community, as their ecological optima lie in another vegetation type, but which can survive under suboptimal conditions (accessory or satellite species). In such a way, all habitat types, being natural or non-natural, can constitute sources of additional plant species and thus contribute to increasing local grassland diversity (the so-called spatial mass effects; Hanski, 1982; Öster et al., 2007; Pärtel et al., 2001; Shmida and Wilson, 1985).

The influence of the surrounding landscape, in terms of heterogeneity and habitat cover (so-called matrix variables), has already been studied at different scales and on different taxa and species groups, e.g. neophytes, specialist or generalist species (Dauber et al., 2003; Reitalu et al., 2012; Schmucki et al., 2012; Söderström et al., 2001). Most studies of plant diversity in semi-natural grasslands relate the landscape structure to a relatively large area (e.g. patches, islands, floristic mapping grid-cells or municipalities), whereas the investigation of small-scale grassland diversity is rare (e.g. Löbel et al., 2006; Reitalu et al., 2012; Schmucki et al., 2012). This approach cannot adequately address the processes controlling diversity patterns in complex landscapes where grassland species occur in a variety of habitats (Schmucki et al., 2012). With few exceptions (Schmucki et al., 2012; Turtureanu and Dengler, 2012), the majority of recent studies focus solely on the pattern of alpha diversity without considering simultaneously the patterns of beta and gamma diversity. Partitioning species diversity into its alpha, beta and gamma components is useful for assessing the spatial structure of diversity patterns. As a measure of variation in species composition between sites, the beta component connects diversity measures across scales, i.e. between the local (alpha) and the regional (gamma) diversities (Anderson et al., 2011; Schmucki et al., 2012; Tuomisto, 2010). Understanding the factors determining each of these components and their interrelationships provide useful insights into the mechanisms that determine plant diversity in heterogeneous landscapes. Since different diversity components are driven by different ecological processes, they also provide important information for nature conservation, as conservation strategies based upon single measurements are not recommended (Turtureanu and Dengler, 2012). Finally, studies, which would confirm the significance of the surrounding landscape structure on a large dataset covering multiple habitats distributed over large areas, are completely missing. The recent developments of large vegetation databases provide an opportunity to utilize such data for detailed analysis of landscape effects on grassland diversity. Vegetation plots represent a valuable source of diversity data as they provide the species list recorded at a geographically referenced site within a defined plot area (Dengler et al., 2011). In this article, we used a large vegetation-plot database of Slovakia (Central Europe) comprising several thousands of plots, to test the effects of landscape context on the plant diversity components (alpha, beta and gamma) within grassland types of varying soil moisture conditions.

From the total area of grasslands in Slovakia $\left(5420 \mathrm{~km}^{2}\right.$ representing $11 \%$ of the Slovak territory) about $60 \%$ are classified as high nature value (HNV) grasslands $\left(3230 \mathrm{~km}^{2}\right.$, Galvánek, 2010). Due to diverse geological, geomorphological and climatic conditions as well as varying land-use histories, these grassland ecosystems are very diverse and species-rich. From 1940 to 1990, traditional land use was more and more restricted in most regions of Slovakia and replaced by cooperatives and state farms. During this period, ploughing, intensification, over-fertilization and overgrazing lead to large-scale degradation and destruction of grassland habitats (Šeffer et al., 2002). Since 1990, the transformation to a market-based economy has been associated with a decline in cattle and sheep breeding, and large grassland areas became abandoned and overgrown by shrubs, expansive grasses or invasive alien plants. Recently, the maintenance of high nature value semi-natural grasslands has become a major challenge for effective nature conservation (Veen et al., 2009). As such grasslands still represent important biodiversity hotspots in the intensively used landscape, knowledge of landscape effects on their diversity patterns are of special importance.

The objective of this paper is to assess the relative importance of landscape structure (i.e. percentage cover and diversity of surrounding habitats) to alpha, beta, and gamma diversities and species composition of semi-natural grasslands in Slovakia. We analyzed all grasslands combined and four main grassland types grouped according to their soil moisture (xerophilous, subxerophilous, mesophilous and wet) separately. All analyses were performed on vegetation plots from the Slovak Vegetation Database (Šibík, 2012), one of the largest vegetation-plot databases in central Europe (Schaminée et al., 2009). Specifically, we address the following questions:

i) How are the plant species richness (alpha diversity), betweenplot diversity (beta diversity) and cumulative number of species (gamma diversity) of semi-natural grasslands affected by the structure of the surrounding landscape?

ii) Do the surrounding habitats affect the species composition of grasslands?

iii) Does the local (alpha) diversity and species composition of different grassland types (xerophilous, sub-xerophilous, mesophilous and wet) respond differently to the structure of the surrounding landscape?

\section{Materials and methods}

\subsection{Semi-natural grasslands in Slovakia}

According to the recent phytosociological survey of Slovakia (Janišová et al., 2007), semi-natural grasslands are represented by 76 associations belonging to 17 alliances and nine orders. For this study, we grouped the nine orders into four main types: (i) xerophilous grasslands (narrow-leaved sub-continental steppes of Festucetalia valesiacae and rocky grasslands of Stipo pulcherrimae-Festucetalia pallentis); (ii) sub-xerophilous grasslands (broad-leaved semi-dry grasslands of Brometalia erecti and Koelerio-Phleetalia phleoidis); (iii) mesophilous grasslands (mesophilous Arrhenatherum meadows, pastures and park grasslands and montane mesophilous meadows of Arrhenatheretalia elatioris, as well as submontane and montane Nardus grasslands of Nardetalia strictae) and (iv) wet grasslands (wet meadows, intermittently wet Molinia meadows and alluvial meadows of lowland rivers of Molinietalia as well as vegetation of wet disturbed soils of Potentillo-Polygonetalia and Plantagini-Prunelletalia). Xerophilous and sub-xerophilous grasslands are distributed mainly in the warmer regions and at lower altitudes. Mesophilous and wet grasslands are distributed throughout most of Slovakia, being absent only in the high mountains and larger lowlands with intensive agricultural utilization (Appendix A). 


\subsection{Preparation of the dataset}

The dataset for analysis was extracted from the Slovak Vegetation Database (Šibík, 2012; code EU-SK-001 in the Global Index of Vegetation-Plot Databases, Dengler et al., 2011), originally containing 51,180 plots of all vegetation types (as of 1 January 2011) using the following procedure:

i) Vegetation plots of semi-natural grassland communities including the phytosociological classes Festuco-Brometea (orders Festucetalia valesiacae, Stipo pulcherrimae-Festucetalia pallentis, Brometalia erecti and Koelerio-Phleetalia phleoidis), MolinioArrhenatheretea (orders Arhenatheretalia elatioris, Molinietalia, Potentillo-Polygonetalia, Plantagini-Prunelletalia and Poo alpinae-Trisetetalia) and Nardetea strictae (only alliances Nardo-Agrostion tenuis and Violion caninae within the phytosociological order Nardetalia strictae, Janišová et al., 2007) were selected.

ii) Only plots with accurate geographical location and plot size of $25 \mathrm{~m}^{2}$ were included (the recording date ranged from 1933 to 2010).

iii) Only plots from altitudes of up to $1600 \mathrm{~m}$ were included, which corresponds to the natural timberline in the Western Carpathian Mts.

iv) Only plots with cover of shrub and/or tree layers lower than $25 \%$ were included.

To reduce the effect of oversampling in certain areas, this dataset was geographically stratified (Knollová et al., 2005). One plot of each syntaxon (determined in most cases at the level of associations by the original author) was randomly selected from a grid square of $0.5^{\prime}$ longitude and $0.3^{\prime}$ latitude (approximately $0.60 \mathrm{~km} \times 0.56 \mathrm{~km}$ ). The dataset was inspected visually, and plots with apparently incorrect syntaxonomic affiliation (mainly extremely species-poor plots containing wetland or aquatic species) and plots with incorrect header data (mainly geographical coordinates from outside Slovakia), were removed (58 plots). Then the expert system for identification of Slovak grassland vegetation (Janišová et al., 2007) was applied to the dataset and each plot matching a definition (41\% of plots) was assigned to the respective association, while the rest of plots (59\%) were ordered to associations according to the Frequency Positive Fidelity Index (FPFI; Tichý, 2005). Thirty two plots with FPFI values lower than 10 were excluded from the dataset (these represented mainly incomplete plots with only few species). Finally, 3795 plots with 1221 vascular plant species remained for analysis. In this dataset, distances between plots were calculated to indicate overlaps of studied plot surroundings and possible pseudoreplication. As the proportion of plots with overlapping surroundings was lower than $1 \%$, pseudoreplication was negligible and we therefore did not remove further plots from the dataset. According to the identification of associations by the expert system, each of the plots was assigned to one of the four grassland types (a) xerophilous grasslands (315 plots), (b) sub-xerophilous grasslands (362 plots), (c) mesophilous grasslands (2294 plots) and (d) wet grasslands (824 plots).

Multiple records of species in different layers within a plot were combined, so that each species appeared in each plot only once. Bryophytes and lichens were deleted, as they were not recorded in all plots. Juvenile trees and shrubs were deleted, too. Plant taxonomy was unified according to the checklist of Marhold and Hindák (1998). In several cases, when the application of the narrow species concept from the checklist was not possible, taxa were defined as broader aggregates, mainly following Janišová et al. (2007). Nomenclature of syntaxa follows Janišová et al. (2007).

\subsection{Landscape characteristics}

The effects of land use were studied in plot neighbourhoods of $4 \mathrm{~km}^{2}$ (a circle with a radius of $1.128 \mathrm{~km}$ centred at the plot) and $1 \mathrm{~km}^{2}$ size (radius of $0.564 \mathrm{~km}$ ). According to the CORINE land cover maps (Bossard et al., 2000), 26 habitat classes were distinguished in the neighbourhood of the studied plots. For the purpose of this study, they were combined into two main (natural and seminatural vs. non-natural) and four subordinate habitat categories (non-forest, forest, agricultural, artificial) as summarized in Table 1. In addition to landscape parameters calculated from CORINE land cover maps, percentage cover of ecologically valuable grasslands was estimated according to the National Grassland Inventory based on field surveys performed during 1998-2010 (Šeffer et al., 2002). For the purposes of this study, valuable grasslands are defined as biodiverse grasslands of higher nature value. They included $88 \%$ of the mapped grasslands (intensively used, fertilized and ruderal grasslands were excluded from this category directly during the field survey). The percentage cover values of six habitat categories based on the CORINE land cover maps and one category based on the National Grassland Inventory were related to diversity components.

The index of habitat diversity was calculated for each plot based on the cover of habitat classes in the plot neighbourhood as $H^{\prime}=-\sum p_{i} \ln p_{i}$, where $p_{i}$ is the proportion of each of the habitat class. The index was calculated for the diversity of (i) all habitats, (ii) natural and semi-natural habitats, (iii) natural and semi-natural non-forest habitats, and (iv) non-natural habitats. Plots were divided into four categories with equal range according to the index values, and the diversity components of these groups were compared.

\subsection{Calculation of diversity components}

Plant species diversity was partitioned into alpha, beta and gamma components. These components were defined for the purposes of this paper as follows:

i) Alpha diversity: species richness of vascular plants in individual vegetation plots $\left(25 \mathrm{~m}^{2}\right)$.

ii) Gamma diversity: cumulative number of species estimated for 30 or 100 nearest plots (cumulative area 750 and $2500 \mathrm{~m}^{2}$, respectively).

iii) Beta diversity (between-plot diversity): variability between plots within a defined group. Beta diversity was calculated using Whittaker's multiplicative approach (Whittaker, 1960), i.e. gamma diversity divided by alpha diversity.

The importance of landscape factors for determining alpha diversity was studied by regression tree analysis. The whole dataset, as well as individual grassland types, were analyzed separately. Each decision tree was pruned (prune of variance) after the data were split, with a minimum of 100 cases per branch and a maximum of 1000 nodes per tree. A $v$-fold cross-validation was used to adjust the optimal tree size ( $v$-value set to 10 and number of cross-validated classification errors set to 1 ). The relative importance of each predictor variable for producing the final tree was calculated according to Breiman (1984) using the STATISTICA program (StatSoft Inc., 2006). The importance plots ranking the predictors on a $0-100$ scale were used to determine which variable is the most significant predictor.

Differences in alpha diversity between grassland types and land-use categories were tested using the analysis of variance and unequal N HSD test in the STATISTICA program (StatSoft Inc., 2006). Categories containing less than 20 plots were not subjected to evaluation. Series of simple linear and quadratic regressions were 
Table 1

Definition of habitat types used in this study based on habitat classes of CORINE land cover maps (Bossard et al., 2000).

\begin{tabular}{|c|c|c|}
\hline Habitat types & & CORINE habitat class \\
\hline Natural and semi-natural habitats & 更 & $\begin{array}{l}\text { 2.3.1 Pastures } \\
\text { 2.4.3 Land principally occupied by agriculture with significant areas of } \\
\text { natural vegetation } \\
\text { 3.2.1 Natural grasslands } \\
\text { 3.2.2 Moors and heathland } \\
\text { 3.2.4 Transitional woodland-scrub } \\
\text { 3.3.2 Bare rocks } \\
\text { 3.3.3 Sparsely vegetated areas } \\
\text { 4.1.1 Inland marshes } \\
\text { 4.1.2 Peat bogs }\end{array}$ \\
\hline & Forest habitats & $\begin{array}{l}\text { 3.1.1 Broad-leaved forest } \\
\text { 3.1.2 Coniferous forest } \\
\text { 3.1.3 Mixed forest }\end{array}$ \\
\hline Non-natural habitats & Agricultural habitats & $\begin{array}{l}\text { 2.1.1 Non-irrigated arable land } \\
\text { 2.2.1 Vineyards } \\
\text { 2.2.2 Fruit trees and berry plantations } \\
\text { 2.4.2 Complex cultivation patterns }\end{array}$ \\
\hline & Artificial habitats & $\begin{array}{l}\text { 1.1.1 Continuous urban fabric } \\
\text { 1.1.2 Discontinuous urban fabric } \\
\text { 1.2.1 Industrial or commercial units } \\
\text { 1.2.2 Road and rail networks and associated land } \\
\text { 1.2.4 Airports } \\
\text { 1.3.1 Mineral extraction sites } \\
\text { 1.3.2 Dump sites } \\
\text { 1.3.3 Construction sites } \\
\text { 1.4.1 Green urban areas } \\
\text { 1.4.2 Sport and leisure facilities }\end{array}$ \\
\hline
\end{tabular}

performed for alpha diversity as the dependent variable and 11 landscape factors as continuous predictors. Bonferroni correction was used setting critical values of $\alpha$ as $\alpha / 11$. The Akaike information criterion (AIC) was used to select the most appropriate model.

For each proportional category and diversity of surrounding habitats, spatially constrained sample-based rarefaction curves (Chiarucci et al., 2009) were calculated. Generally, sample-based rarefaction curves describe the average number of accumulated species as sampling effort increases and thus allow comparing two or more datasets with originally different sampling effort by standardizing to the same sampling effort or, in our case, same number of vegetation plots. Rarefaction curves include information about average alpha, beta and gamma diversity because the first point of such a curve represents average alpha diversity, the slope of the curve indicates the combination of alpha and beta diversity and the end point indicates the gamma diversity, or the diversity of a large area (Colwell et al., 2004; Gotelli and Colwell, 2001; Riccota et al., 2002). The statistical differences between rarefaction curves can be evaluated by comparison of the confidence intervals. If the confidence intervals overlap, the difference is not significant (Colwell et al., 2004). The special type of sample-based rarefaction is a spatially constrained variant of the described procedure, which is suitable for comparing samples that were drawn from areas of different spatial extent (Chiarucci et al., 2009). Standard rarefaction would not yield reliable results in such a situation because due to the distance decay of similarity, the curve would increase more steeply for a set of samples collected across larger spatial extent than for a regional sub-set of the same data. Spatially constrained rarefaction partly avoids this artefact by sequential selecting of the nearest plots when calculating accumulation curves which are afterwards averaged (Chiarucci et al., 2009). We used an implementation of this idea by A. Ghisla, G. Bacaro, D. Michalcová and D. Zelený (unpubl.) in the statistical environment $\mathrm{R}$ (version 2.11.1, $\mathrm{R}$ Development Core Team), following the method described in Chiarucci et al. (2009). This method was slightly modified in that each vegetation plot was used as the starting point of one accumulation curve, i.e. the number of accumulation curves was equal to the number of plots in each dataset, and all these curves were than averaged, and their 95\% confidence intervals were calculated and curves were visualized.

Two different variants of beta diversity - multiplicative (Whittaker, 1960) and additive (Lande, 1996) - were calculated from the rarefaction curves. To calculate multiplicative beta diversity we divided gamma diversity under comparable sampling effort, i.e. cumulative species richness in 30 and 100 vegetation plots, respectively, by mean species richness in one plot. This procedure was repeated for all accumulation curves in each dataset, averaged, and the $95 \%$ confidence intervals were estimated. To calculate additive beta diversity the similar procedure was employed but subtraction was used instead of division. As the results obtained by both methods were qualitatively similar, while additive beta diversity has been criticized for its dependence on total species richness (gamma component; e.g. Baselga, 2010; Turtureanu and Dengler, 2012), we decided to present only the multiplicative version.

\subsection{Species sub-set of target grassland species}

Along with the analyses of the whole dataset (including all species recorded in the plots) we analyzed a data sub-set containing only target grassland species (995 of all 1221 species). Alien species (according to Medvecká et al., 2012) and species typical of non-natural and forest habitats (species with the highest fidelity to urban, agricultural and forest habitats calculated on the whole Slovak Vegetation Database, including plots of all syntaxa) were excluded (see Appendix B). As the results for the whole dataset and for the dataset of the target species were similar, we present only the results for the whole dataset. In addition, we studied whether the number, percentage proportion and cover of species typical of forest habitats were related to the proportion of forest habitats in the plot neighbourhoods. Similarly, the proportions of species typical of non-natural habitats in the plots (including alien species - archaeophytes and neophytes - and native species with high fidelity to non-natural habitats) were studied in relation to the proportion of non-natural habitats in plot neighbourhoods. 
Proportion of natural and semi-natural habitats

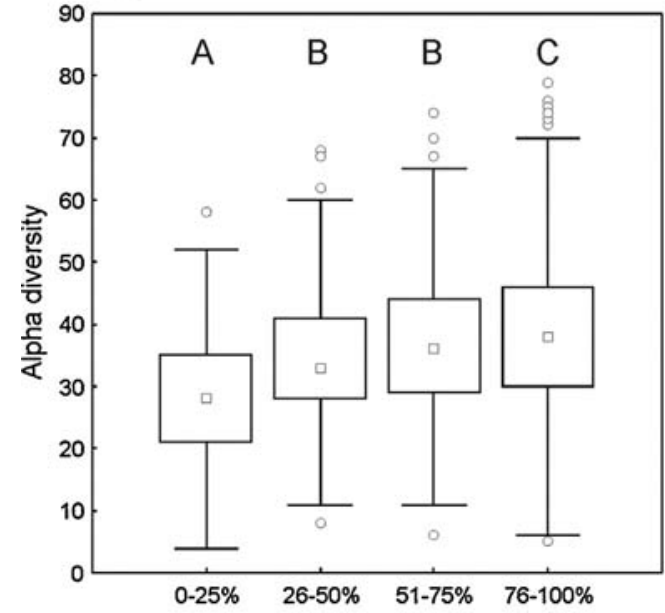

Proportion of non-natural habitats

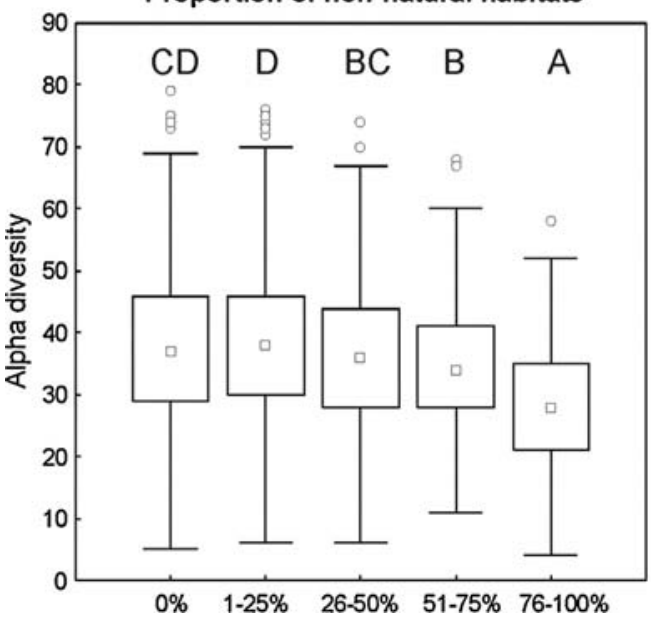

Diversity of natural and semi-natural habitats

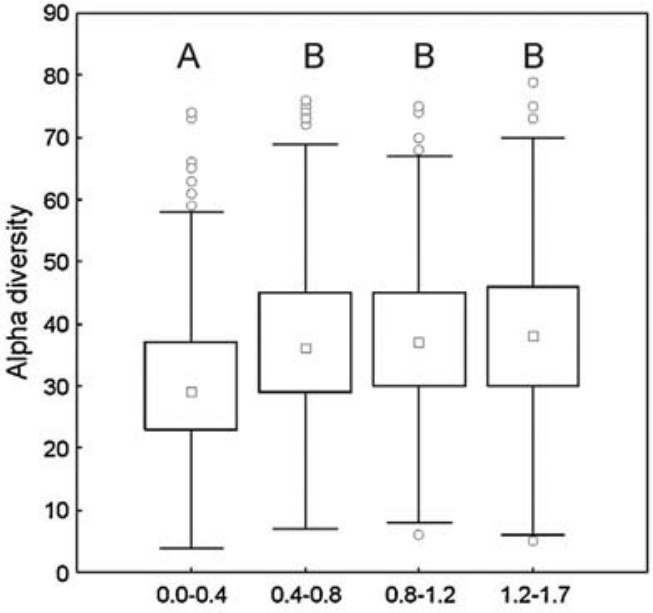

Diversity of non-natural habitats

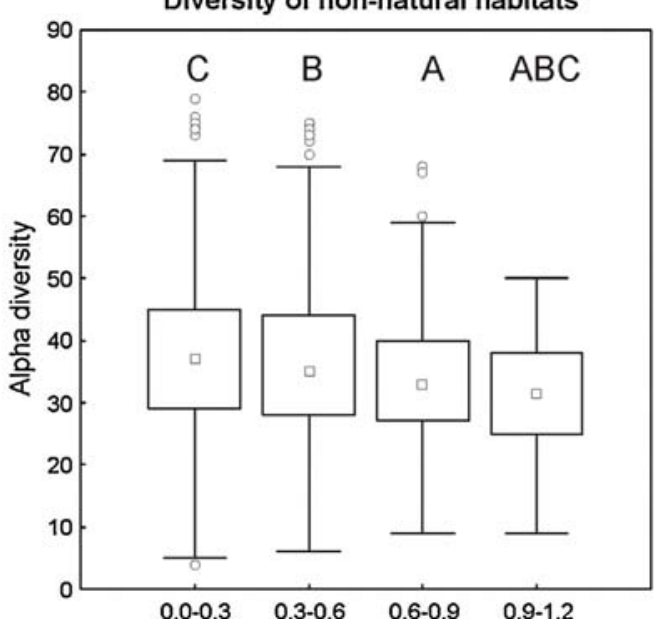

Fig. 1. Alpha diversity $\left(25 \mathrm{~m}^{2}\right)$ of grasslands with different proportion and diversity of natural and semi-natural versus non-natural habitats in the plot neighbourhood. Differences among the groups were tested by the analysis of variance (ANOVA) at $\alpha=0.05$. Results of multiple comparison tests are indicated by letters. Median, $25-75 \%$ quartiles (box), non-outlier range (whisker) and outliers are shown.

\section{Results}

\subsection{Overall patterns of diversity}

The results of our analyses were similar at both scales (i.e. $1 \mathrm{~km}^{2}$ or $4 \mathrm{~km}^{2}$ ) but the studied landscape factors showed stronger effects on diversity components at larger scales. Also the combination of different habitats was more diverse in larger plot neighbourhoods so we decided to present only the results for the neighbourhood areas of $4 \mathrm{~km}^{2}$ in this article. The alpha diversity of semi-natural grasslands increased with increasing proportion and diversity of natural and semi-natural habitats in the plot neighbourhood. Contrastingly, increasing proportion and diversity of non-natural habitats was associated with decrease in plot alpha diversity (Fig. 1, Tables 2 and 3). These general trends were true also if individual habitat types were studied (non-forest and forest habitats distinguished within the natural and semi-natural habitats and agricultural and artificial habitats distinguished within the non-natural habitats, Tables 2 and 3; Appendix C). The landscape factors explained normally only a small fraction of variance in plot-scale richness (0-13.1\%), whereby the explained variance was highest in the semi-dry basiphilous grasslands (Table 3 ).

Multiplicative beta diversity had the highest values in grasslands surrounded by the lowest proportion and lowest diversity of natural and semi-natural habitats (Fig. 2a and e). Gamma diversity was high in grasslands with an intermediate proportion or diversity of natural and semi-natural habitats in the plot neighbourhood (Fig. 2b and f). Plots surrounded by the largest proportion (75-100\%) of natural and semi-natural habitats had the lowest gamma diversity (Fig. 2b). Plots surrounded by a larger proportion (50-75\%) of non-natural habitats had higher beta (Fig. 2c) and gamma (Fig. 2d) diversities than plots with less (0-50\%) non-natural habitats in their neighbourhood. The higher the diversity of non-natural habitats in plot neighbourhoods was, the higher were their beta (Fig. 2g) and gamma (Fig. 2h) diversities.

Among the studied landscape factors, proportion of natural and semi-natural habitats and proportion of valuable grasslands were most important in producing the regression tree for predicting alpha diversity (Fig. 3) in the dataset including all grassland types. The highest alpha diversity was found in plots with a neighbourhood composed of at least 35\% of natural and semi-natural habitats and simultaneously containing at least some valuable grasslands (more than 1.5\%). The proportion and diversity of natural and seminatural habitats in the plot neighbourhood (which positively affect alpha diversity) were more important for construction of a regression tree than proportion and diversity of non-natural habitats (which negatively affected alpha diversity). 
Table 2

Alpha diversity (species richness at $25 \mathrm{~m}^{2}$ ) of main grassland types and land-use categories. Differences tested by the analysis of variance and multiple comparison tests at $\alpha=0.05$ are indicated by letters.

\begin{tabular}{|c|c|c|c|}
\hline & Category & No. of plots & Alpha diversity \\
\hline Grassland type & $\begin{array}{l}\text { Xero } \\
\text { Sub-xero } \\
\text { Meso } \\
\text { Wet }\end{array}$ & $\begin{array}{r}315 \\
362 \\
2294 \\
824\end{array}$ & $\begin{array}{l}31.0^{\mathrm{a}} \\
46.5^{\mathrm{c}} \\
38.3^{\mathrm{b}} \\
29.8^{\mathrm{a}}\end{array}$ \\
\hline $\begin{array}{l}1 \text { Natural and semi-natural } \\
\text { habitats }(\%)\end{array}$ & $\begin{array}{l}1-25 \% \\
26-50 \% \\
51-75 \% \\
76-100 \%\end{array}$ & $\begin{array}{r}421 \\
411 \\
653 \\
2310\end{array}$ & $\begin{array}{l}28.1^{\mathrm{a}} \\
34.6^{\mathrm{b}} \\
36.6^{\mathrm{b}} \\
38.5^{\mathrm{c}}\end{array}$ \\
\hline $\begin{array}{l}\text { 1.1. Natural and semi-natural } \\
\text { non-forest habitats (\%) }\end{array}$ & $\begin{array}{l}1-25 \% \\
26-50 \% \\
51-75 \% \\
76-100 \%\end{array}$ & $\begin{array}{r}1794 \\
1317 \\
529 \\
155\end{array}$ & $\begin{array}{l}35.2^{\mathrm{a}} \\
38.0^{\mathrm{b}} \\
38.0^{\mathrm{b}} \\
36.8^{\mathrm{ab}}\end{array}$ \\
\hline 1.1.1 Valuable grasslands (\%) & $\begin{array}{l}1-25 \% \\
26-50 \% \\
51-75 \% \\
76-100 \%\end{array}$ & $\begin{array}{r}3064 \\
575 \\
148 \\
8\end{array}$ & $\begin{array}{l}36.1^{\mathrm{a}} \\
39.3^{\mathrm{b}} \\
36.3^{\mathrm{ab}} \\
\text { Not considered }\end{array}$ \\
\hline 1.2 Forest habitats $(\%)$ & $\begin{array}{l}0 \% \\
1-25 \% \\
26-50 \% \\
51-75 \% \\
76-100 \%\end{array}$ & $\begin{array}{l}404 \\
868 \\
906 \\
841 \\
776\end{array}$ & $\begin{array}{l}28.6^{a} \\
36.1^{b} \\
37.9^{c} \\
38.0^{c} \\
38.2^{c}\end{array}$ \\
\hline 2 Non-natural habitats (\%) & $\begin{array}{l}0 \% \\
1-25 \% \\
26-50 \% \\
51-75 \% \\
76-100 \%\end{array}$ & $\begin{array}{r}1165 \\
1235 \\
655 \\
378 \\
362\end{array}$ & $\begin{array}{l}37.8^{\mathrm{cd}} \\
38.6^{\mathrm{d}} \\
36.5^{\mathrm{bc}} \\
34.7^{\mathrm{b}} \\
28.4^{\mathrm{a}}\end{array}$ \\
\hline 2.1 Agricultural habitats (\%) & $\begin{array}{l}0 \% \\
1-25 \% \\
26-50 \% \\
51-75 \% \\
76-100 \%\end{array}$ & $\begin{array}{r}1499 \\
1123 \\
620 \\
345 \\
208\end{array}$ & $\begin{array}{l}38.1^{d} \\
38.0^{d} \\
35.6^{c} \\
32.8^{b} \\
27.4^{a}\end{array}$ \\
\hline 2.2 Artificial habitats (\%) & $\begin{array}{l}0 \% \\
1-25 \% \\
26-50 \% \\
51-75 \%\end{array}$ & $\begin{array}{r}2020 \\
1656 \\
96 \\
21\end{array}$ & $\begin{array}{l}37.6^{\mathrm{b}} \\
35.6^{\mathrm{a}} \\
33.3^{\mathrm{ab}} \\
34.5^{\mathrm{ab}}\end{array}$ \\
\hline 3 Diversity of all habitats & $\begin{array}{l}0.00-0.50 \\
0.51-1.00 \\
1.01-1.50 \\
>1.50\end{array}$ & $\begin{array}{r}334 \\
909 \\
2003 \\
549\end{array}$ & $\begin{array}{l}33.3^{\mathrm{a}} \\
36.5^{\mathrm{b}} \\
37.1^{\mathrm{b}} \\
37.3^{\mathrm{b}}\end{array}$ \\
\hline $\begin{array}{l}\text { 3.1 Diversity of natural and } \\
\text { semi-natural habitats }\end{array}$ & $\begin{array}{l}0.00-0.40 \\
0.41-0.80 \\
0.81-1.20 \\
>1.20\end{array}$ & $\begin{array}{r}538 \\
1122 \\
1534 \\
601\end{array}$ & $\begin{array}{l}30.4^{\mathrm{a}} \\
37.4^{\mathrm{b}} \\
37.6^{\mathrm{b}} \\
38.2^{\mathrm{b}}\end{array}$ \\
\hline $\begin{array}{l}\text { 3.1.1 Diversity of natural and } \\
\text { semi-natural non-forest habitats }\end{array}$ & $\begin{array}{l}0.00-0.25 \\
0.26-0.50 \\
0.51-0.75 \\
>0.75\end{array}$ & $\begin{array}{r}874 \\
1462 \\
1184 \\
275\end{array}$ & $\begin{array}{l}33.5^{\mathrm{a}} \\
37.5^{\mathrm{b}} \\
37.8^{\mathrm{b}} \\
37.2^{\mathrm{b}}\end{array}$ \\
\hline $\begin{array}{l}3.2 \text { Diversity of non-natural } \\
\text { habitats }\end{array}$ & $\begin{array}{l}0.0-0.3 \\
0.3-0.6 \\
0.6-0.9 \\
>0.9\end{array}$ & $\begin{array}{r}2257 \\
1212 \\
296 \\
30\end{array}$ & $\begin{array}{l}37.4^{\mathrm{c}} \\
36.1^{\mathrm{b}} \\
33.1^{\mathrm{a}} \\
31.0^{\mathrm{abc}}\end{array}$ \\
\hline
\end{tabular}

\subsection{Particularities of the four main grassland types}

The studied grassland types differed significantly in alpha diversity, sub-xerophilous grasslands having the highest values, followed by mesophilous grasslands and both xerophilous and wet grasslands had the lowest species richness (Table 2). Regression trees together with linear or quadratic regression models revealed that high proportions of valuable grasslands in plot neighbourhoods best predicted high alpha diversity of xerophilous or wet grasslands. For sub-xerophilous and mesophilous grasslands, high alpha diversity was best predicted by the proportion of natural and semi-natural habitats (including the valuable grasslands), followed by the proportion of non-natural habitats (Table 3, Fig. 3).
The average number, proportion and cover of typical forest species increased with increasing proportion of forest habitats in the plot neighbourhood in all the main grassland types, except xerophilous grasslands (Fig. 4a). The proportion of archaeophytes increased with increasing proportion of non-natural habitats in the plot neighbourhood in all grassland types, while the proportion of neophytes increased only in mesophilous and wet grasslands (Fig. 4b). The proportion of species of non-natural habitats (including alien species and native species typical of non-natural habitats) increased with increasing proportion of nonnatural habitats in all grassland types except wet grasslands, where the proportion was very high independently of the proportion of non-natural habitats in the plot neighbourhood. The increase 
Table 3

Summary of simple regression models for alpha diversity $\left(25 \mathrm{~m}^{2}\right)$ as dependent variable and landscape factors as predictors. Linear and quadratic relationships were compared and the model with lower AIC is presented by arrows $\uparrow$ or $\downarrow$ for linear relationships, $\cap$ for hump-back and $\cup$ for U-shape quadratic relationships. Percentage variance of dependent variable explained by the model is shown in the parentheses. Scatter plots are shown in Appendix C. Significant relationships were indicated after using Bonferroni correction, ${ }^{*} P<0.05,{ }^{* *} P<0.01$ and ${ }^{* * *} P<0.001$, n.s. - non significant.

\begin{tabular}{|c|c|c|c|c|c|}
\hline & All grasslands & Xero & Sub-xero & Meso & Wet \\
\hline 1 Natural and semi-natural habitats (\%) & $\cap^{* * *}(8.0)$ & $\cap^{*}(3.3)$ & $\uparrow^{* * *}(13.1)$ & $\cap^{* * *}(4.3)$ & $\cap^{* * *}(6.5)$ \\
\hline 1.1 Natural and semi-natural non-forest habitats (\%) & $\cap^{* * *}(2.2)$ & n.s. & $\cap^{*}(3.6)$ & n.s. & $\cap^{* * *}(7.3)$ \\
\hline 1.1.1 Valuable grasslands (\%) & $\cap^{* * *}(4.4)$ & $\cap^{* * *}(8.3)$ & $\cap^{* * *}(8.5)$ & $\cap^{* * *}(1.2)$ & $\cap^{* * *}(5.5)$ \\
\hline 1.2 Forest habitats $(\%)$ & $\cap^{* * *}(4.3)$ & n.s. & $\cap^{* * *}(10.0)$ & $\cap^{* * *}(1.7)$ & $\cap^{* *}(2.0)$ \\
\hline 2 Non-natural habitats (\%) & $\cap^{* * *}(6.2)$ & $\cap^{*}(3.7)$ & $\cap^{* * *}(12.7)$ & $\cap^{* * *}(3.8)$ & $\cap^{* * *}(4.6)$ \\
\hline 2.1 Agricultural habitats (\%) & $\cap^{* * *}(5.4)$ & n.s. & $\downarrow^{* * *}(11.3)$ & $\cap^{* * *}(3.0)$ & $\cap^{* * *}(2.9)$ \\
\hline 2.2 Artificial habitats (\%) & $\cup^{* * *}(1.2)$ & n.s. & n.s. & $\cup^{*}(0.5)$ & n.s. \\
\hline 3 Diversity of all habitats & $\cap^{* * *}(0.7)$ & n.s. & n.s. & n.s. & $\cap^{* *}(1.7)$ \\
\hline 3.1 Diversity of natural and semi-natural habitats & $\cap^{* * *}(4.7)$ & n.s. & $\cap^{* * *}(6.0)$ & $\cap^{* * *}(1.1)$ & $\cap^{* * *}(5.4)$ \\
\hline 3.1.1 Diversity of natural and semi-natural non-forest habitats & $\cap^{* * *}(2.3)$ & n.s. & $\cap^{* *}(4.9)$ & n.s. & $\cap^{* * *}(4.1)$ \\
\hline 3.2 Diversity of non-natural habitats & $\cap^{* * *}(1.4)$ & n.s. & $\cap^{* * *}(5.7)$ & $\cap^{* * *}(1.0)$ & n.s. \\
\hline
\end{tabular}

was most pronounced in mesophilous and xerophilous grasslands (Fig. 4b).

\section{Discussion}

Our study revealed that the alpha diversity is partly affected by both the percentage cover and diversity of different habitats surrounding the studied plots. Generally, the alpha diversity of the observed grasslands increased with increasing diversity or percentage cover of different natural and semi-natural habitats in the plot neighbourhood. Conversely, alpha diversity decreased with higher proportion or diversity of non-natural habitats in the surroundings. Although there probably act also local abiotic and biotic factors forming species composition and influencing alpha diversity (e.g. Löbel et al., 2006; Michalcová et al., 2011; Reitalu et al., 2012), we believe that there are also important mechanisms operating on regional scale: (i) connectivity of grasslands related to the species pool effect (e.g. Pärtel et al., 1996; Zobel, 1992, 1997) and (ii) isolation of grasslands related to both the species pool effect as well as the spatial mass effect (Hettenbergerová and Hájek, 2011; Pulliam, 1988; Shmida and Wilson, 1985). Connectivity of grasslands, i.e. the proportion of semi-natural non-forest habitats in plot neighbourhood, means that these habitat types may constitute sources of species to a particular plot (Bruun, 2000; Cantero et al., 1999; Reitalu et al., 2012). In other words, the species pool is larger and also the probability of extinction of local populations will be reduced (Hájková et al., 2011). In contrast, isolation, whereby the plots resemble islands surrounded by contrasting habitats, means that the number of grassland species in the plot neighbourhood is lower, i.e. the species pool is smaller. In such a situation, the probability of extinction of local populations in the grassland plots increases and simultaneously the source habitat is too distant to counterbalance the species loss by colonization (Bruun, 2000; Eriksson et al., 2002; MacArthur and Wilson, 1967). However, through the spatial mass effect, some species which occur more frequently in the surrounding non-grassland habitats, the so-called satellite species (Pärtel et al., 2001), can spread into the studied grassland plots and thus increase the alpha diversity. Although both the species pool and spatial mass effects potentially constitute sources of species to the grassland plots, our results suggest that the effect of the species pool is stronger than spatial mass effect. This means that more isolated plots with small species pools of grassland species have a low alpha diversity; albeit some e.g. ruderal or weed species may spread from neighbouring arable fields or artificial habitats.

Although the landscape structure affects the alpha diversity of all the grassland types in question, alpha diversity in subxerophilous and mesophilous grasslands was more susceptible to changes in landscape structure than alpha diversity in xerophilous or wet grasslands (Table 3). The explanation for this could be the position of sub-xerophilous and mesopilous grasslands in the middle of the moisture gradient, where there are suitable conditions for generalist species. According to Steiner and Köhler (2003), the importance of spatial mass effect for alpha diversity increases with an increasing proportion of habitat generalists in a community, as generalists can survive in a variety of habitats. Thus, through the spatial mass effect the spread of forest species into the subxerophilous grasslands or the ruderal and weed species into the mesophilous grasslands (Fig. 4) with increasing cover of forests or non-natural habitats is more pronounced. In contrast, xerophilous and wet grasslands are situated at the extreme ends of this gradient, where there are inappropriate environmental conditions for the majority of species occurring in adjacent habitats. These extreme conditions act as a filter promoting a rather small group of specialist species confined to a particular grassland type (Zobel, 1992). Thus the spatial mass effect does not shape the species composition and related alpha diversity so strongly (e.g. Hettenbergerová and Hájek, 2011), although, for example, xerophilous grasslands were enriched by archaeophytes (Fig. 4).

Several studies have also emphasized the importance of habitat quality in the surrounding landscape for dispersal of local organisms (Hansson et al., 1995; Harrison and Bruna, 1999; Schmucki et al., 2012; Söderström et al., 2001). In our study, neighbouring valuable grasslands, which represent high-quality habitats preserving grassland diversity, significantly enhanced the alpha diversity of all grassland types, especially the xerophilous or wet grasslands. Plots surrounded by a high proportion of valuable grasslands likely have been sampled in large grassland complexes with a long history of continuous management. Previous studies had found that both size of grassland site (e.g. Bruun, 2000; Öster et al., 2007) and extensive history of management (e.g. Hájková et al., 2011; Pärtel et al., 1996; Purschke et al., 2012) have a positive impact on plant alpha diversity. The higher importance of valuable grasslands in the surrounding landscape indicated in xerophilous and wet grasslands, might be a consequence of the higher proportion of specialists in these grasslands (Hettenbergerová and Hájek, 2011) whereas in mesophilous grasslands rich in generalist species the importance of valuable grasslands in the plot neighbourhood was lower (Fig. 3).

The high local (alpha) diversity does not necessarily mean high beta or regional (gamma) diversity. In contrast, grassland plots with high alpha diversity promoted by their location within large grassland complexes (Fig. 2a and b, 76-100\%), had low beta and gamma diversity. We believe that the low beta diversity of plots with high local diversity was caused mainly by the species pool effect, whereby species mainly colonize from the surrounding grasslands, and therefore the species composition of such plots is similar. By contrast, the low compositional similarity and thus also 

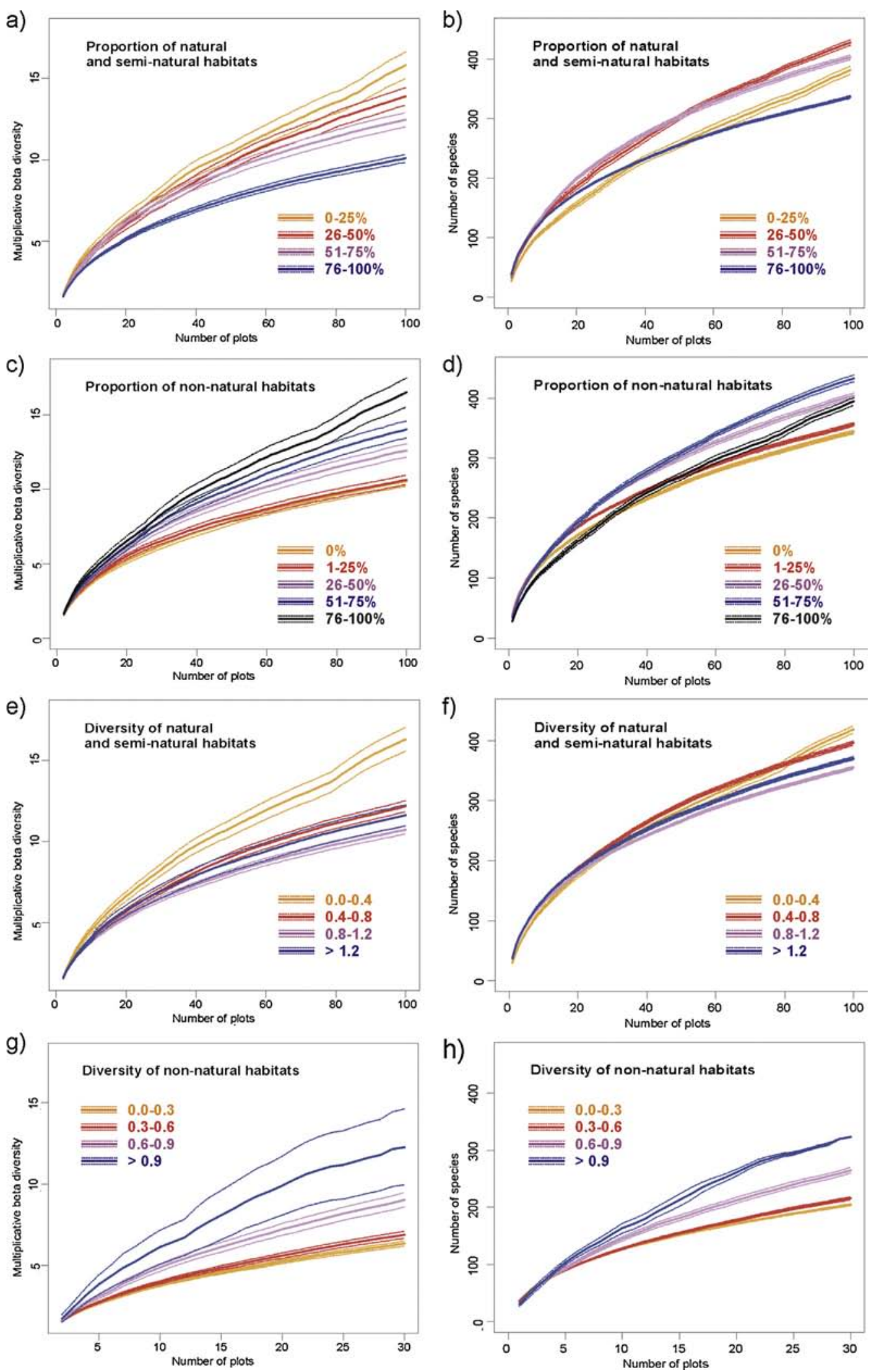

Fig. 2. Multiplicative beta diversity curves and spatially constrained sample-based rarefaction curves of grasslands with different proportions and diversity of natural and semi-natural versus non-natural habitats in the neighbourhoods.

high beta and gamma diversity of plots surrounded by contrasting habitats is caused mainly by the spatial mass effect. Because the composition of the surrounding landscape varies, various species, especially generalists, can migrate into the plots. Similar trends were found also if specific grassland types (xerophilous, subxerophilous, mesophilous or wet) were analyzed separately.

Our results for landscape effects (circular landscapes with radii of 564 and $1128 \mathrm{~m}$ ) did not generally differ from smaller or 

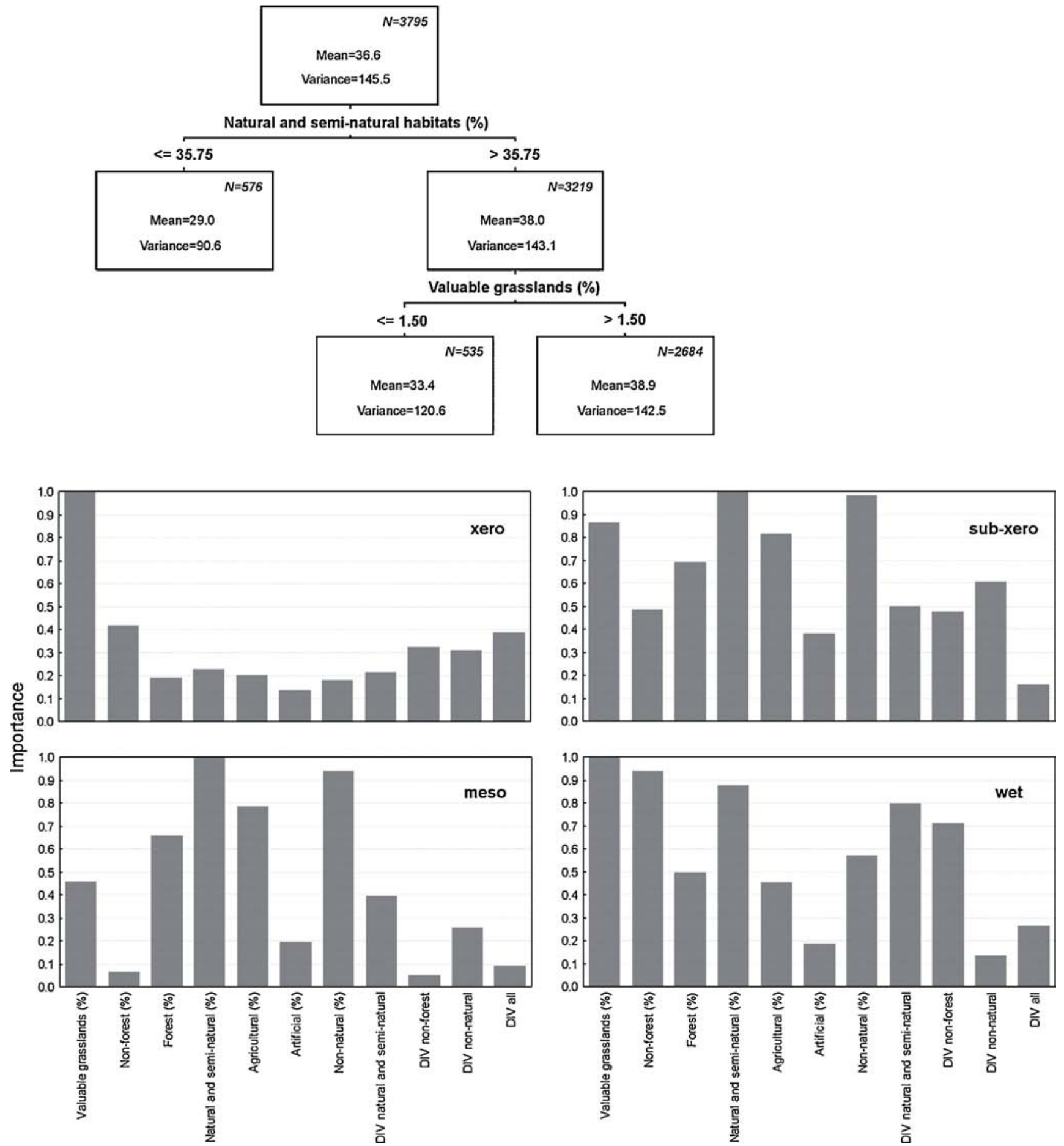

Fig. 3. Regression tree for the whole dataset (including all grassland types and all species), explaining the alpha diversity ( $25 \mathrm{~m}^{2}$ ) using landscape factors (above). Relative importance of landscape factors for prediction of alpha diversity by a regression tree in the four grassland types (below).

similar-scale comparisons made by Söderström et al. $\left(2001 ; 1 \mathrm{~km}^{2}\right.$ area), Öster et al. (2007; circular landscape with a 2000-m radius), Reitalu et al. (2012; 300-m radius around grassland patches) or Schmucki et al. (2012; circular landscape with a 500-m radius). The more diverse the landscape was and the greater the proportion of surrounding grasslands (Reitalu et al., 2012), forests (Öster et al., 2007) or open land (Schmucki et al., 2012) the more species were found at the plot-scale. On the other hand, the alpha diversity of various taxa (vascular plants, butterflies and birds) decreased with an increasing proportion of urban elements or arable fields in the surrounding landscape (Söderström et al., 2001). However, there also exist studies where the importance of the landscape structure as a factor explaining plant diversity patterns was not confirmed. E.g. Löbel et al. (2006) found that unlike cryptogam richness, the plot scale richness of vascular plants was not influenced by the landscape-scale effects.

An important aspect that should be considered when interpreting our results is that we assumed the land use within the observed grasslands to be stable or with possible changes at random. Although the vegetation plots stored in our database were recorded 
a)

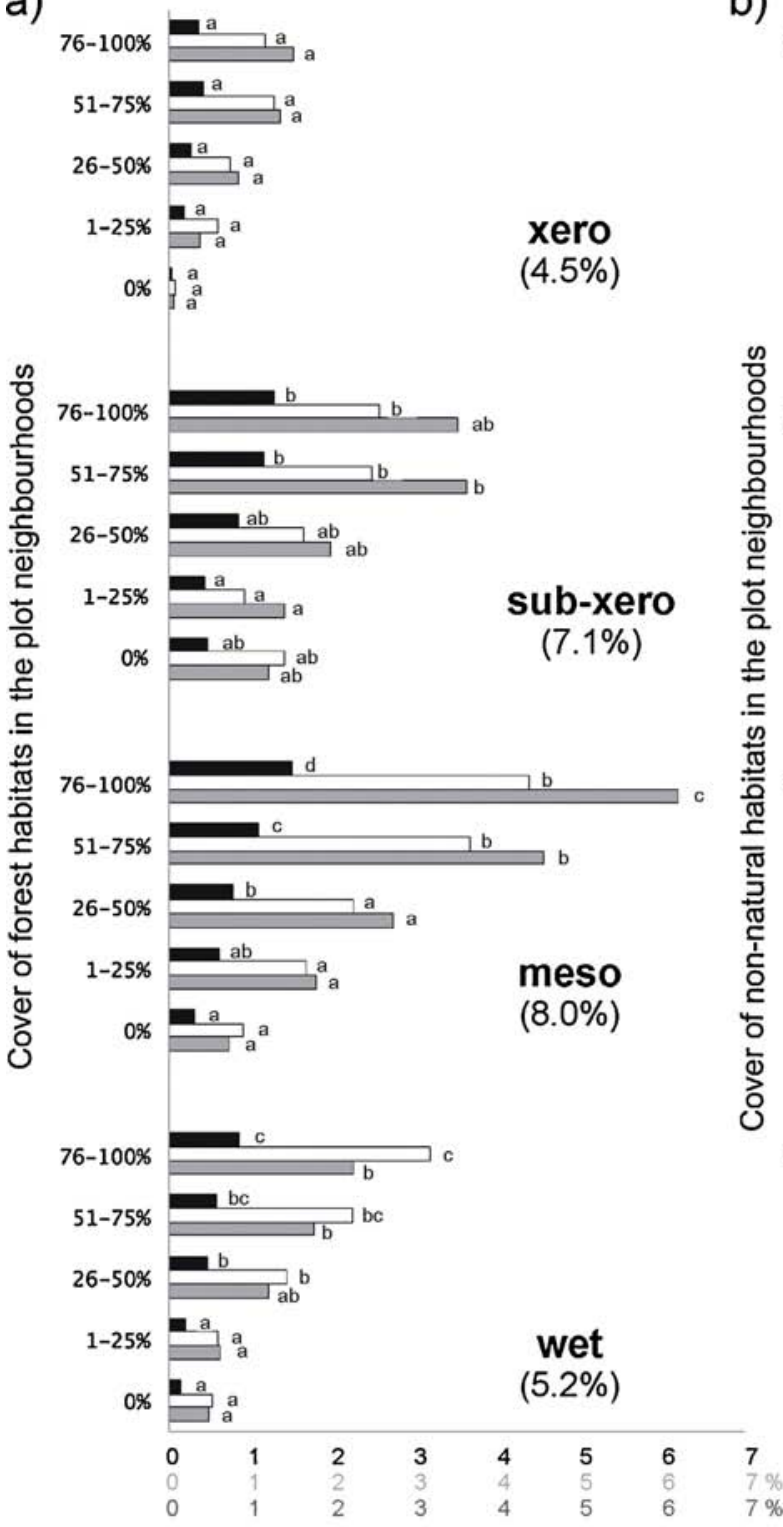

Legend:

b)

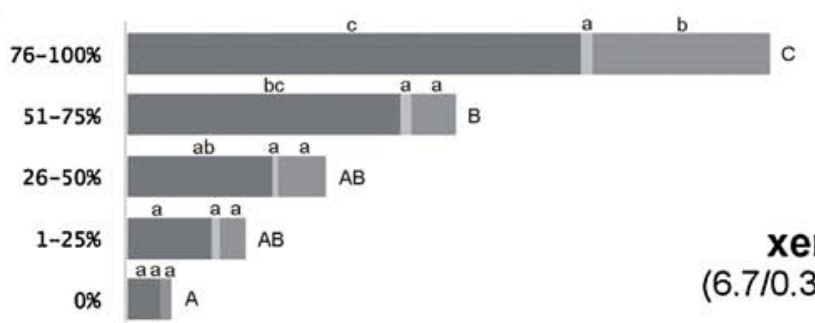

xero
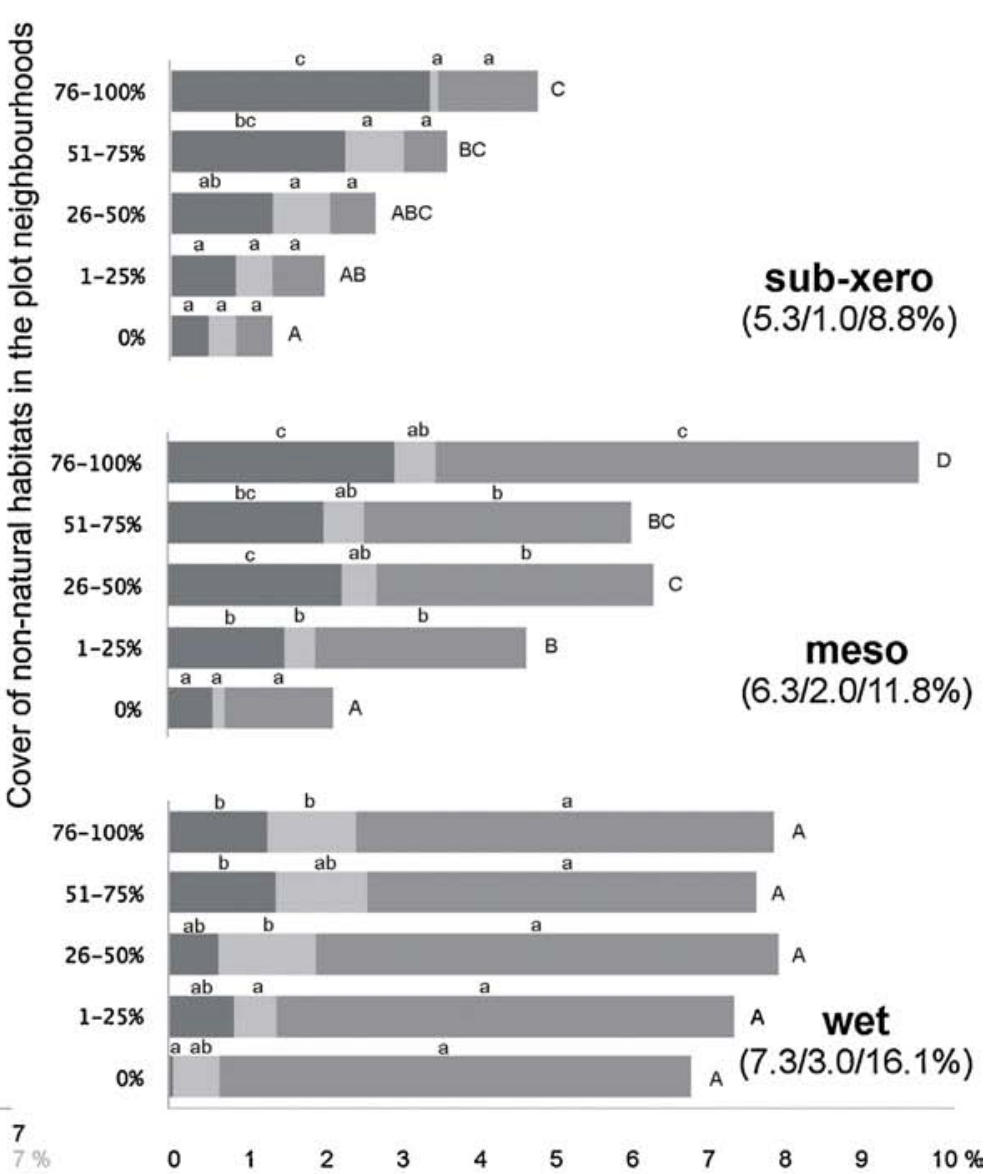

Mean proportion of species of non-natural habitats

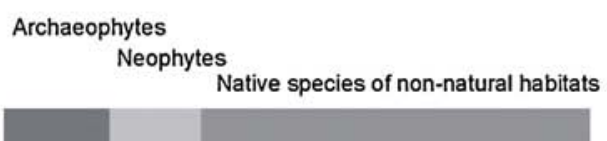

Fig. 4. (a) Mean number, mean proportion and mean cover of species with a high fidelity to forest habitats in plots of four main grassland types, in relation to the cover of forest habitats in the plot neighbourhood. Percentage of forest species in the sub-sets is shown in parentheses. (b) Mean proportion of alien species (archaeophytes and neophytes) and native species with high fidelity to non-natural habitats in plots of four main grassland types in relation to the proportion of non-natural habitats in the plot neighbourhood. Percentages of archaeophytes, neophytes and all species of non-natural habitats in data sub-sets are shown in parentheses. Differences between categories were tested by the analysis of variance (ANOVA) at $\alpha=0.05$ and the results of multiple comparison tests are indicated by letters (capitals indicate the overall difference in the sum of all three categories).

over a long period of several decades, the temporal dimension of processes acting at landscape scale has not been subjected to investigation. We are aware of the increasing number of studies documenting that landscape history is of great importance for present-day diversity and abundance patterns (Bruun et al., 2001; Cousins and Eriksson, 2002; Helm et al., 2006) and that the differences in landscape history of individual regions might have influenced also our results (Socher et al., 2013). However, thanks to the large size and coverage of the vegetation-plot database we used (Šibík, 2012), we could confirm the previously reported effects of the surrounding landscape in multiple habitats (all types of semi-natural grasslands) over a large area of a whole country (Slovakia). The general trends indicated in our study using a large vegetation-plot database correspond well with the conclusions of most comparative and experimental studies focussing not only on plant diversity but also on diversity of birds and invertebrate communities (Batáry et al., 2007; Krauss et al., 2004; Söderström et al., 2001). This emphasizes the relevance of data stored in large vegetation-plot databases which can be used as a tool for the detection of diversity 
patterns over large areas (Dengler et al., 2011; Schaminée et al., 2009).

\section{Implication for nature conservation}

From the nature conservation viewpoint, the influence of landscape structure on the typical grassland species, rather than the whole species assemblage, is relevant. The complete species list could include also species which are undesirable for nature conservation, e.g. alien, nitrophilic, ruderal and forest species, which often occur in the initial stages of succession leading to secondary woodland. For this reason, all analyses were performed also on vegetation plots containing only typical grassland species, together with some generalists (i.e. forest species, alien species and species typical of non-natural habitats were excluded). The detected trends regarding alpha, beta and gamma diversity were similar to those calculated for the whole species assemblage. Therefore we conclude that, although the local diversity is enhanced by migration of species from contrasting adjacent habitats (Fig. 4), the connectivity and diversity of semi-natural habitats (or on the contrary, the isolation of grassland plots), play a more important role than spatial mass effect in determining the diversity of grassland communities (e.g. Reitalu et al., 2012). Although the relatively small, isolated grassland patches may not develop as high local species richness as larger ones, they still have conservation value because many valuable grassland species will persist there (Eriksson et al., 2002) and enhance the grassland diversity at the landscape scale. However, the conclusion of former studies (Öster et al., 2007; Reitalu et al., 2012) that diverse landscape surroundings may provide additional species and thus buffer the negative influence of fragmentation and isolation of grassland habitats was confirmed also by our study. It is therefore important to protect grasslands containing conservationally important species to maintain their presence in the species pool and in the network of grassland habitats. Such a strategy of maintaining populations of vulnerable and threatened species will also in turn, enhance gamma diversity.

Our results also show that the effects of the surrounding landscape can differ much in various grassland types and therefore the conservation measures adopted to support their diversity should also vary. Xerophilous grasslands can be much enriched by the surrounding valuable grasslands but are only little affected by surrounding forest habitats. At the same time they are susceptible to colonization by archaeophytes and some native species of non-natural habitats. Wet grasslands should be preserved mainly within larger complexes of ecologically valuable grasslands with high diversity of other natural and semi-natural non-forest habitats. Forest species from surrounding forest habitats may colonize wet grasslands and slightly increase their alpha diversity. Some wet grasslands contain high proportions of alien species and species typical of non-natural habitats but this proportion does not clearly depend on the presence and cover of non-natural habitats in the plot neighbourhood. Sub-xerophilous and mesophilous grasslands can be enriched by all types of natural and semi-natural habitats in their neighbourhood. Forest species and species typical of nonnatural habitats mainly colonize mesophilous grasslands, resulting in higher total alpha diversity but a lower proportion of target species in the stands. For these communities, the conservation value should be estimated on the basis of estimates of target species richness rather than total species richness.

\section{Acknowledgements}

We are grateful to Rastislav Lasák (Daphne-Institute of applied ecology) for providing us with data from the National Grassland
Inventory and the calculation of habitat cover in plot neighbourhood, Ondřej Hájek for calculation of distances among the plot pairs, Milan Chytrý, Jürgen Dengler, Pavol Král' and three anonymous referees for advice and valuable comments, Stephen Venn for linguistic editing of the manuscript and to all those who have contributed to the Slovak vegetation database. Financial support: VEGA 2/0099/13 (to M.J.).

\section{Appendix A. Supplementary data}

Supplementary data associated with this article can be found, in the online version, at http://dx.doi.org/10.1016/j.agee.2013.05.022.

\section{References}

Akatov, V., Chefranov, S., Akatova, T., 2005. The relationship between local species richnes and species pool: a case study from the high mountains of the Greater Caucaus. Plant Ecol. 181, 9-22.

Anderson, M., Crist, T., Chase, J., Vellend, M., Inouye, B., Freestone, A., Sanders, N.J., Cornell, H.V., Comita, L.S., Davies, K.F., Harrison, S.P., Kraft, N.J.B., Stegen, J.C., Swenson, N.G., 2011. Navigating the multiple meanings of beta diversity: a roadmap for the practicing ecologist. Ecol. Lett. 14, 19-28.

Baselga, A., 2010. Multiplicative partition of true diversity yields independent alpha and beta components; additive partition does not. Ecology 91, 1974-1981.

Batáry, P., Báldi, A., Szél, G., Podlussány, A., Rozner, I., Erdös, S., 2007. Responses of grassland specialists and generalist beetles to management and landscape diversity. Divers. Distrib. 13, 196-202.

Bossard, M., Feranec, J., Ot'ahel, J., 2000. CORINE Land Cover Technical GuideAddendum 2000. European Environmental Agency, Copenhagen.

Breiman, L., 1984. Classification and Regression Trees. Chapman \& Hall/CRC, New York.

Bruun, H.H., 2000. Patterns of species richness in dry grassland patches in an agricultural landscape. Ecography 23, 641-650.

Bruun, H.H., Fitzbøger, B., Rindel, P.O., Lund Hansen, U., 2001. Plant species richness in grasslands: the relative importance of contemporary environment and landuse history since the Iron Age. Ecography 24, 569-578.

Cantero, J.J., Pärtel, M., Zobel, M., 1999. Is species richness dependent on the neighbouring stands? An analysis of the community patterns in mountain grasslands of central Argentina. Oikos 87, 346-354.

Chiarucci, A., Bacaro, G., Rocchini, D., Ricotta, C., Palmer, M.W., Scheiner, S.M., 2009. Spatially constrained rarefaction incorporating the autocorrelated structure of biological communities into sample-based rarefaction. Comm. Ecol. 10, 209-214.

Chytrý, M., 2012. Vegetation of the Czech Republic. Preslia 84, 427-504.

Colwell, R.K., Mao, C.X., Chang, J., 2004. Interpolating, extrapolating, and comparing incidence-based species accumulation curves. Ecology 85, 2717-2727.

Cousins, S.A.O., Eriksson, O., 2002. The influence of management history and habitat on plant species richness in a rural hemiboreal landscape. Landsc. Ecol. 17, 517-529.

Dauber, J., Hirsch, M., Simmering, D., Waldhardt, R., Otte, A., Wolters, W., 2003. Landscape structure as an indicator of biodiversity: matrix effects on species richness. Agric. Ecosyst. Environ. 98, 321-329.

Dengler, J., Jansen, F., Glöckler, F., Peet, R.K., De Cáceres, M., Chytrý, M., Ewald, J., Oldeland, J., Lopez-Gonzalez, G., Finckh, M., Mucina, L., Rodwell, J.S., Schaminée, J.H.J., Spencer, N., 2011. The global index of vegetation-plot databases (GIVD): a new resource for vegetation science. J. Veg. Sci. 22, 582-597.

Ellenberg, H., 1996. Vegetation Mitteleuropas mit den Alpen in ökologischer, dynamischer und historischer Sicht. Ulmer, Stuttgart.

Eriksson, O., Cousins, S.A.O., Bruun, H.H., 2002. Land-use history and fragmentation of traditionally managed grasslands in Scandinavia. J. Veg. Sci. 13, 743-748.

Galvánek, D., 2010. High Nature Value grasslands in Slovakia-current state. In: Kizeková, M., Pollák, Š. (Eds.), SALVERE, Semi-Natural Grassland as a Source of Biodiversity Improvement. Grassland and Mountain Agriculture Research Institute, Banská Bystrica, pp. 15-17.

Gotelli, N.J., Colwell, R.K., 2001. Quantifying biodiversity: procedures and pitfalls in the measurement and comparison of species richness. Ecol. Lett. 4, 379-391.

Grime, J.P., 2001. Plant Strategies, Vegetation Processes, and Ecosystems Properties. John Wiley \& Sons, Chichester

Hájková, P., Roleček, J., Hájek, M., Horsák, M., Fajmon, K., Polák, M., Jamrichová, E., 2011. Prehistoric origin of the extremely species-rich semi-dry grasslands in the Bílé Karpaty Mts (Czech Republic and Slovakia). Preslia 83, 185-204.

Hanski, I., 1982. Dynamics of regional distribution: the core and satellite species hypothesis. Oikos 38, 210-221.

Hansson, L., Fahrig, L., Merriam, G., 1995. Mosaic Landscapes and Ecological Processes. Chapman \& Hall, London.

Harrison, S., Bruna, E., 1999. Habitat fragmentation and large scale conservation: what do we know for sure? Ecography 22, 225-232.

Helm, A., Hanski, I., Pärtel, M., 2006. Slow response of plant species richness to habitat loss and fragmentation. Ecol. Lett. 9, 72-77.

Hettenbergerová, E., Hájek, M., 2011. Is species richness of small spring fens influenced by the spatial mass effect? Comm. Ecol. 12, 202-209. 
Janišová, M., Hájková, P., Hegedüšová, K., Hrivnák, R., Kliment, J., Michálková, D. Ružičková, H., Řezníčková, M., Tichý, L., Škodová, I., Uhliarová, E., Ujházy, K., Zaliberová, M., 2007. Travinnobylinná vegetácia Slovenska-elektronický expertný systém na identifikáciu syntaxónov. Botanický ústav SAV, Bratislava.

Knollová, I., Chytrý, M., Tichý, L., Hájek, O., 2005. Stratified resampling of phytosociological databases: some strategies for obtaining more representative data sets for classification studies. J. Veg. Sci. 16, 479-486.

Krauss, J., Klein, A.-M., Steffan-Dewenter, I., Tscharntke, T., 2004. Effects of habitat area, isolation, and landscape diversity on plant species richness of calcareous grasslands. Biodivers. Conserv. 13, 1427-1439.

Lande, R., 1996. Statistics and partitioning of species diversity, and similarity among multiple communities. Oikos 76, 5-13.

Löbel, S., Dengler, J., Hobohm, C., 2006. Species richness of vascular plants, bryophytes and lichens in dry grasslands: the effects of environment, landscape structure and competition. Folia Geobot. 41, 377-393.

MacArthur, R.H., Wilson, E.O., 1967. The Theory of Island Biogeography. Princeton Univ. Press, Princeton.

Marhold, K., Hindák, F., 1998. Zoznam nižších a vyšších rastlín Slovenska. VEDA Bratislava http://ibot.sav.sk/checklist (accessed on 20.02.2013).

Medvecká, J., Kliment, J., Májeková, J., Halada, L., Zaliberová, M., Gojdičová, E., Feráková, V., Jarolímek, I., 2012. Inventory of the alien flora of Slovakia. Preslia 84 257-309.

Michalcová, D., Gilbert, J.C., Lawson, C.S., Gowing, D.J.G., Marrs, R.H., 2011. The combined effect of waterlogging, extractable $\mathrm{P}$ and soil $\mathrm{pH}$ on $\alpha$-diversity: a case study on mesotrophic grasslands in the UK. Plant Ecol. 212, 879-888.

Öster, M., Cousins, S.A.O., Eriksson, O., 2007. Size and heterogeneity rather than landscape context determine plant species richness in semi-natural grasslands. J. Veg. Sci. 18, 859-868.

Pärtel, M., Zobel, M., Zobel, K., van der Maarel, E., 1996. The species pool and its relation to species richness: evidence from Estonian plant communities. Oikos 75, 111-117.

Pärtel, M., Moora, M., Zobel, M., 2001. Variation in species richness within and between calcareous (alvar) grassland stands: the role of core and satellite species. Plant Ecol 157, 205-213.

Pulliam, H.R., 1988. Sources, sinks and population regulation. Am. Nat. 132, 652-661.

Purschke, O., Sykes, M.T., Reitalu, T., Poschlod, P., Prentice, H.C., 2012. Linking landscape history and dispersal traits in grassland plant communities. Oecologia 168 773-783.

Reitalu, T., Purschke, O., Johansson, L.J., Hall, K., Sykes, M.T., Prentice, H.C., 2012 Responses of grassland species richness to local and landscape factors depend on spatial scale and habitat specialization. J. Veg. Sci. 23, 41-51.

Riccota, C., Carranza, M.L., Avena, G., 2002. Computing $\beta$-diversity from species area curves. Basic Appl. Ecol. 3, 15-18.
Schaminée, J.H.J., Hennekens, S.M., Chytrý, M., Rodwell, J.S., 2009. Vegetation-plot data and databases in Europe: an overview. Preslia 81, 173-185.

Shmida, A., Wilson, M.V., 1985. Biological determinants of species diversity. J. Biogeogr. 12, 1-20.

Schmucki, R., Reimark, J., Lindborg, R., Cousins, S.A.O., 2012. Landscape context and management regime structure plant diversity in grassland communities. J. Ecol. 100, 1164-1173.

Socher, S.A., Prati, D., Boch, S., Müller, J., Baumbach, H., Gockel, S., Hemp, A., Schöning, I., Wells, K., Buscot, F., Kalko, E.K.V., Linsenmair, K.E., Schulze, E.-D., Weisser, W.W., Fischer, M., 2013. Interacting effects of fertilization, mowing and grazing on plant species diversity of 1500 grasslands in Germany differ between regions. Basic Appl. Ecol. 14, 126-136.

Söderström, B., Svensson, B., Vessby, K., Glimskär, A., 2001. Plants, insects and birds in semi-natural pastures in relation to local habitat and landscape factors. Biodivers. Conserv. 10, 1839-1863.

StatSoft Inc., 2006. Electronic Statistics Textbook. Statsoft, Tulsa http://www. statsoft.com/text-book/stahme.html (31.1.2013).

Steiner, N.C., Köhler, W., 2003. Effects of landscape patterns on species richness-a modelling approach. Agric. Ecosyst. Environ. 98, 353-361.

Šeffer, J., Lasák, R., Galvánek, D., Stanová, V., 2002. Grasslands of Slovakia. Final report on National Grassland Inventory 1988-2002. DAPHNE-Institute of Applied Ecology, Bratislava.

Šibík, J., 2012. Slovak vegetation database. Biodivers. Ecol. 4, 429.

Tichý, L., 2005. New similarity indices for the assignment of relevés to the vegetation units of an existing phytosociological classification. Plant Ecol. 179, $67-72$.

Tuomisto, H., 2010. A diversity of beta diversities: straightening up a concept gone awry. Part 2. Quantifying beta diversity and related phenomena. Ecography 33, $23-45$.

Turtureanu, P.D., Dengler, J., 2012. Different aspects of plant diversity show contrasting patterns in Carpathian forest openings. Plant Ecol. 213 67-76.

Veen, P., Jefferson, R., de Smidt, J., van der Straaten, J. (Eds.), 2009. Grasslands in Europe of High Nature Value. KNNV Publishing, Zeist.

Wilson, J.B., Peet, K.P., Dengler, J., Pärtel, M., 2012. Plant species richness: the world records. J. Veg. Sci. 23, 796-802.

Whittaker, R.H., 1960. Vegetation of the Siskiyou mountains, Oregon and California. Ecol. Monogr. 30, 279-338.

Zobel, M., 1992. Plant species coexistence-the role of historical, evolutionary and ecological factors. Oikos 65, 314-320.

Zobel, M., 1997. The relative role of species pools in determining plant species richness: an alternative explanation of species coexistence? Trends Ecol. Evol. 12, 266-269. 